\title{
VPLIV MALIH HIDROELEKTRARN NA POPULACIJO POTOČNE POSTRVI (Salmo trutta L.) NA PRIMERU REKE MISLINJE
}

\author{
Blaž Cokan, univ. dipl. geogr.*, dr. Blaž Repe, dr. geogr.** \\ * Smrečnikovo 4, SI-2392 Mežica \\ ** Oddelek za geografijo, Filozofska fakulteta Univerze v Ljubljani, \\ Aškerčeva 2, SI-I000 Ljubljana \\ e-mail: blaz.cokan@gmail.com, blaz.repe@ff.uni-lj.si \\ Izvirni znanstveni članek \\ COBISS 1.01 \\ DOI: 10.4312/dela.40.1.7-24
}

\section{Izvleček}

Potočno postrv (Salmo trutta L.) v reki Mislinji že desetletje z odvzemom vode iz struge ogrožajo male hidroelektrarne (MHE). Da bi ugotovili njihov vpliv na populacijo potočne postrvi, smo izvedli elektroizlov potočnih postrvi. Ujetim osebkom smo izmerili dolžino in maso. Pridobljene podatke smo analizirali in podali ugotovitve o biomasi, naseljenosti, povprečni masi in dolžini ter številu ujetih osebkov. Ugotovili smo, da se je populacija potočne postrvi na odsekih, kjer odvzemajo vodo za potrebe MHE, zmanjšala.

Ključne besede: zoogeografija, potočna postrv, mala hidroelektrarna, rečni pretok, reka Mislinja

\section{INFLUENCE OF SMALL HYDRO POWER PLANTS ON BROWN TROUT (Salmo trutta L.) POPULATION IN MISLINJA RIVER}

\begin{abstract}
The brown trout (Salmo trutta L.) in the Mislinja River has been endangered for years because of small hydroelectric power plants. To find out how they are affecting the population of the brown trout in the Mislinja River, we conducted a sampling of the brown trout, using a generating set. We measured the length and weight of all caught specimens and analysed the obtained data. The results are presented in this paper, e.g., biomass, estimations of abundance, average weight, average length and number of captured brown trout. We discovered that the population of the brown trout has decreased in all the sections where water has been taken away for small hydroelectric power plants.
\end{abstract}

Key words: zoogeography, brown trout, small hydro power plant, river discharge, Mislinja River, Slovenia 


\section{UVOD}

Potočna postrv (Salmo trutta L.) je avtohtona slovenska vrsta, ki naseljuje reke in potoke v porečju Drave in Save. Zaradi ekoloških zahtev je to vrsta, ki naseljuje le najbolj kakovostne vodotoke v Sloveniji in je zelo občutljiva na kakršnekoli posege v njen življenjski prostor. Zaradi potreb Slovenije po okolju čisti energiji se je v 90-ih letih 20. st. razmahnila gradnja malih hidroelektrarn (MHE) kot način pridobivanja energije na okolju prijaznejši način. Po velikosti in tehničnih zahtevah so to elektrarne, ki se gradijo na majhnih do srednje velikih vodotokih. Obenem so to vodotoki, kjer živi potočna postrv. Tipičen primer takšnega vodotoka je reka Mislinja, na kateri deluje sedem MHE.

Reka Mislinja izvira pod Roglo na Pohorju. V povirnem delu zbira vode iz t. i. Mislinjskega Pohorja, ki leži na južnem do jugozahodnem delu Pohorja oziroma severno od zgornjega dela Mislinjske doline (Gams, 1998). V srednjem toku teče Mislinja po zgornji Mislinjski dolini. V tem delu se s severne strani vanjo izlivajo potoki iz zahodnega Pohorja, od juga pa se vanjo stekajo pritoki izpod Uršlje gore in Graške Gore. Njen največji pritok je reka Suhodolnica. Pri Otiškem Vrhu pri Dravogradu se Mislinja izliva v reko Mežo.

Mislinja ima izrazit hudourniški značaj, posebej v zgornjem toku v Mislinjskem grabnu. Tu poleg neprepustne matične podlage iz metamorfnih in magmatskih kamnin njen hudourniški značaj določa tudi velik strmec. Na desetih kilometrih se Mislinja spusti s

Slika 1: Lokacije treh preučevanih MHE na reki Mislinji

Figure 1: Location of three studied small hydro power plants on the Mislinja River

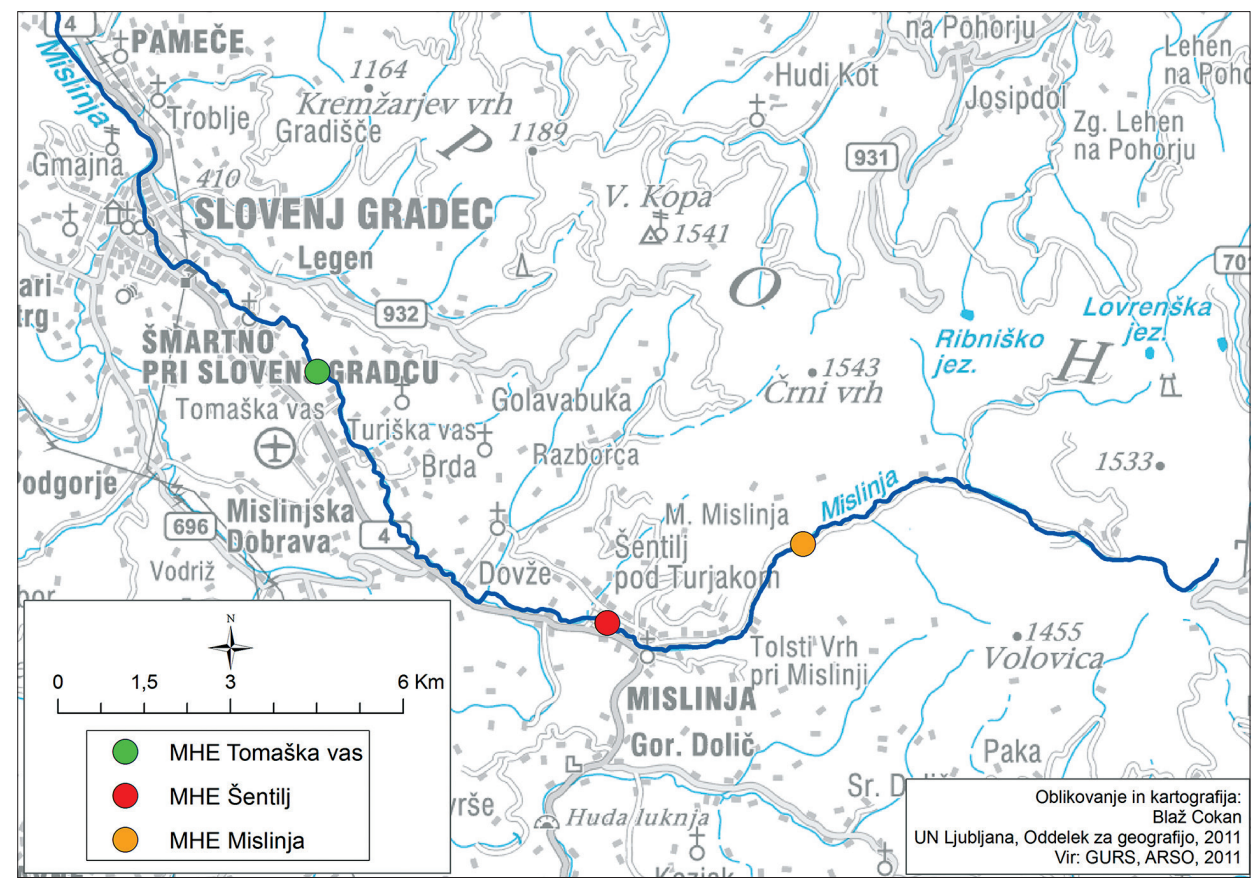


$1443 \mathrm{~m}$ pri izviru na $600 \mathrm{~m}$ v kraju Mislinja. V srednjem in spodnjem delu se njen strmec zmanjša, saj teče po uravnanem delu Mislinjske doline. V tem delu se na 27 kilometrih toka spusti za 200 m, s 600 m na okoli 400 m pri izlivu v Mežo.

Pretoki Mislinje so primerni za izkoriščanje vodne energije v MHE. Leta 2008 je na vodomerni postaji Dovže 1 znašal povprečni letni nizki pretok $0,541 \mathrm{~m}^{3} / \mathrm{s}$, srednji letni pretok $1,7 \mathrm{~m}^{3} / \mathrm{s}$ in povprečni letni veliki pretok $19,2 \mathrm{~m}^{3} / \mathrm{s}$. Absolutno najnižji pretok je v obdobju 1971-2000 znašal $0,202 \mathrm{~m}^{3} / \mathrm{s}$ in sicer 4. avgusta 1993, absolutno najvišji pretok pa $68,0 \mathrm{~m}^{3} / \mathrm{s}$, in sicer 1 . novembra 1990 (Hidrološki letopis Slovenije 2008, 2011). Zaradi velikosti, padca in pretoka je reka Mislinja primerna za izkoriščanje vodne energije v malih hidroelektrarnah, hkrati pa je zaradi teh značilnosti tudi idealen habitat za potočne postrvi.

Namen raziskave je bil ugotoviti vpliv treh MHE (Tomaška vas, Šentilj in Mislinja) na populacijo potočne postrvi na odsekih, kjer vodo odvzemajo iz struge za potrebe MHE. Če bi ugotovili vidne spremembe na populaciji (število, povprečna masa in dolžina, biomasa ter naseljenost), bi poskušali ugotoviti vzroke za te spremembe. Cilj raziskave je bil, da pod vsako MHE na Mislinji posebej z metodo elektroizlova izlovimo vse osebke potočne postrvi na dveh stometrskih odsekih ter na podlagi izmerjenih prametrov izračunamo velikost populacije po posameznih odsekih.

\section{ZNAČILNOSTI POTOČNE POSTRVI}

Potočna postrv spada $\mathrm{v}$ družino salmonidov (Salmonidae). Ima podolgovato in valjasto telo, ki je ob straneh sploščeno. Gobec ima razklan vse do oči in je poln nekoliko nazaj ukrivljenih zob. Za samce je značilna navzgor ukrivljena spodnja čeljust, ki je posebej izražena $v$ času drsti. Kot vsi salmonidi ima tudi potočna postrv med repno in hrbtno plavutjo tolsto plavut oziroma tolščenko, ki je brez plavutnic. Barvitost potočne postrvi je v večji meri pogojena z življenjskim okoljem, v katerem živi, in je odvisna od trenutne osenčenosti oziroma osvetljenosti habitata ter barve rečnega dna. Značilne so rdeče pege na bokih, ki so obrobljene z belo ali modrikasto obrobo. Pojavljajo se tudi črne pege, predvsem na hrbtnem predelu in na glavi. Prav tako se omenjene pege pojavljajo na hrbtni plavuti in tolščenki. Osnovna barva hrbta je svetlo rjava do temno zelena in odvisna od barve okolja. Boke ima svetlejše, trebuh belkast, sivkast ali rumenkast. Luske ima potočna postrv majhne in prekrite s sluzjo. Povprečna dolžina potočne postrvi je okoli 20 do $30 \mathrm{~cm}$, večji primerki nad $50 \mathrm{~cm}$ so redkejši. Maksimalna dolžina je okoli $80 \mathrm{~cm}$ (Svetina, 1987).

V Sloveniji naseljuje hladne in s kisikom bogate alpske, predalpske in kraške potoke ter reke, pojavlja se tudi v submediteranski Sloveniji. Prevladuje v zgornjih delih vodotokov, v t. i. 'postrvjem pasu'. Zanj je značilen hitrejši vodni tok s številnimi brzicami in tolmuni. Njeno bivanje pa ni vezano izključno na postrvji pas, ampak se pojavlja tudi v lipanskem pasu, nekoliko nižje po toku navzdol, kjer se voda že umiri, a je še vedno dobro nasičena s kisikom in ima primerno temperaturo (Hansen, Loeschcke, 1994).

Potočna postrv je ena izmed najbolj pestrih vrst med vsemi ribjimi vrstami. Raz$\log \mathrm{za}$ to je njen razvoj $\mathrm{v}$ času pleistocena in številnih ledenih dob v tem obdobju. Zaradi ledenih dob in širitve ledenikov proti jugu je prišlo do geografske izoliranosti 
posameznih populacij potočne postrvi v Evropi, ki so razvile svoje lastne fenotipske značilnosti. Tako se kažejo razlike med posameznimi populacijami, na primer v času drsti, času zrelosti, toleranci na okolje itd. (Laikre, 1999). Razlog za razlike je tudi izoliranost potočne postrvi po posameznih povodjih, kar pomeni, da je bilo malo ali nič stikov med potočnimi postrvmi v različnih povodjih. Podobno stanje se nadaljuje tudi $\mathrm{v}$ sedanjosti. Kot posledica ločenega razvoja posameznih populacij so se razvijale v pet filogenetskih linij:

- sredozemska linija (zahodni del sredozemskega bazena);

- jadranska linija (vzhodni del sredozemskega bazena z jadranskim povodjem);

- atlantska linija (atlantski bazen);

- linija marmoratus - soška postrv (porečji Pada in Soče) ter

- donavska linija (bazeni Črnega morja ter Kaspijskega in Aralskega jezera).

Raziskava potočne postrvi v reki Mislinji se nanaša na potočno postrv donavske linije. Ključen vpliv na razvoj fenotipskih linij potočne postrvi so imele pleistocenske ledene dobe in z njimi povezane klimatske spremembe ter preoblikovanje površja. Največje klimatske spremembe in preoblikovanje površja v povezavi z ledenimi dobami so se dogajale pred okoli 700.000 leti. Zaradi tega so se ravno v tem času izoblikovala izolirana povodja in porečja, znotraj njih pa so se razvile posamezne fenotipske linije. Zaradi širjenja ledenikov proti jugu Evrope je bil takratni življenjski prostor potočne postrvi močno prizadet. Razvoj donavske linije se je tako začel na območju Črnega morja. Dokončno naj bi se donavska linija razvila pred 300.000-150.000 leti (Bernatchez, 2001).

\section{Slika 2: Potočna postrv (Salmo trutta L.) (foto: Zavod za ribištvo Slovenije)}

Figure 2: Brown trout (Salmno trutta L.) (photo: Fisheries Research Institute of Slovenia)

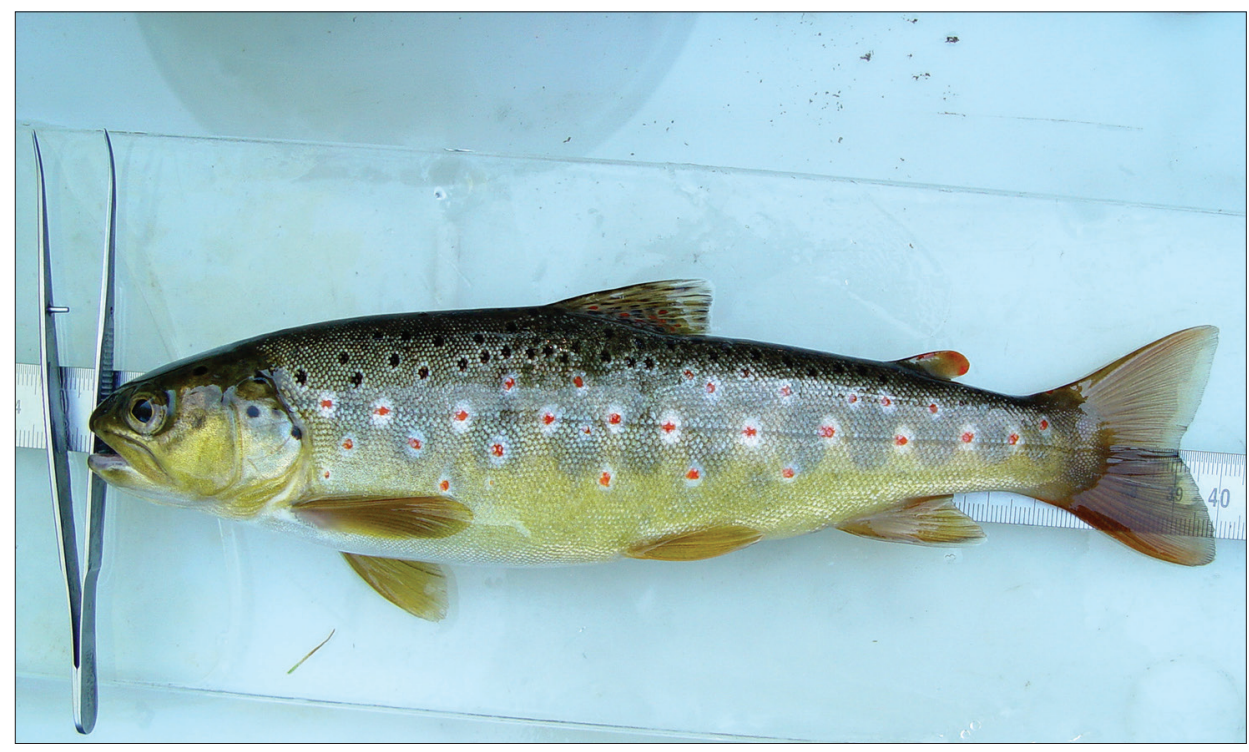




\section{I. Naravni dejavniki, ki vplivajo na velikost populacije potočne postrvi}

Obstaja vrsta naravnih dejavnikov, ki vplivajo na obstoj in velikost populacije potočne postrvi. Ti dejavniki so: globina vode, kritje, temperatura vode, koncentracija raztopljenega kisika v vodi, količina razpoložljive hrane, konkurenca in plenilstvo, substrat ter hitrost vodnega toka.

Globina vode je eden najpomembnejših dejavnikov, ki vpliva na populacijo potočne postrvi. Manjši osebki do $7 \mathrm{~cm}$ navadno zasedajo predele z globino vode od 20 do $30 \mathrm{~cm}$. Večji osebki se, za razliko od manjših, najrajši zadržujejo v najglobljih delih vodotoka tolmunih (Heggenes, 1994). Ti so še posebej pomembni pri potokih in manjših rekah, saj zaradi svoje oblike zadržijo več vode in s tem povečajo globino.

Kritje je skupaj z globino vode najpomembnejši dejavnik, ki omejuje gostoto populacije in produkcijo potočne postrvi (Nielsen, 1986). Potočna postrv je zelo previdna in plašna riba. Če ji omogočimo dovolj kritja, lahko gostota populacije močno naraste (Mortensen, 1977), v nasprotnem primeru se gostota populacije zmanjša. Kot kritje se smatrajo spodjedene brežine, korenine, grmovje in drevje z vejami, podrta drevesa, globoka voda, večji prodniki, manjše skale, vodno rastlinje itd.

Temperaturni optimum za rast potočne postrvi je od $4-19{ }^{\circ} \mathrm{C}$. Nad in pod to mejo nastopi termični stres. Zgornja meja, pri kateri potočna postrv preživi največ 7 dni, je $21,5^{\circ} \mathrm{C}$. Če so postrvi aklimatizirane na višje temperature, se zgornja meja dvigne na $24,7^{\circ} \mathrm{C}$, kar pa ni značilno za potočne postrvi v slovenskih vodotokih. Spodnja meja preživetja je pri $0{ }^{\circ} \mathrm{C}$ (Elliott, 1981).

Koncentracija kisika $v$ vodi se zelo spreminja hkrati s temperaturo vode. $\mathrm{V}$ postrvjih vodah je $\mathrm{v}$ povprečju raztopljenega od $9-12 \mathrm{mg} / \mathrm{l}$ kisika. Kritična meja za preživetje potočne postrvi je okoli 5-6 mg kisika na liter vode.

Za potočne postrvi sta značilna močna konkurenca in kanibalizem med osebki (Bachman, 1984). Ta dejavnika se povečata, kadar abiotske okoliščine omogočajo skupno bivanje več osebkov potočne postrvi ali več različnih vrst. Prav tako se konkurenca in plenilstvo povečata $\mathrm{v}$ poletnih mesecih, ko se zmanjšata globina vode in hitrost toka, temperatura vode in potreba po hrani pa se povečata (Degerman, Sers, 1993). Večji primerki potočne postrvi izbirajo globlje predele rek, da bi se izognili kopenskim plenilcem, manjši primerki pa izbirajo plitvejše predele, da bi se izognili konkurenci in plenilstvu večjih primerkov potočne postrvi (Greenberg, Svendsen, Harby, 1996). Med potočnimi postrvmi največkrat poteka konkurenca za hrano, velikokrat pa se kaže tudi kot tekmovanje za posamezne teritorije (Slaney, Northcote, 1974; Kalleberg, 1958). V obeh primerih dominirajo večji in agresivnejši primerki.

Količina hrane oziroma drifta je prav tako zelo pomemben naravni dejavnik, ki vpliva na populacijo potočne postrvi. Manjše potočne postrvi se hranijo z manjšimi kosi hrane, večje pa z večjimi. To je verjetno posledica razlik v sposobnosti, da ujamejo in pojedo določeno žival (Hart, 1986). Kot hrana prevladujejo ličinke in odrasli osebki enodnevnic, trzačev, mladoletnic in vrbnic. Večji primerki se hranijo z manjšimi ribami. Ko temperatura vode pade pod $4{ }^{\circ} \mathrm{C}$, se hranjenje potočne postrvi ustavi (Elliott, 1981). Hranjenje potočne postrvi je najintenzivnejše spomladi, kar je verjetno vezano 
na obilico hrane v tem času, in kadar je potreba po energiji večja. Intenziteta hranjenja se zmanjša na minimum v zimskih mesecih (Rasmussen, 1986). Potočne postrvi med hranjenjem ne branijo svojega teritorija kot točno določenega območja, ampak branijo predvsem nekaj mest, s katerih imajo ob čim manjši porabi energije prost pogled na živali v driftu. Prav število teh mest naj bi odločilno vplivalo na gostoto populacije potočne postrvi (Bachman, 1984).

Hitrost vodnega toka in substrat sta pomembna dejavnik za izbiro mikrohabitata potočne postrvi, a ne vplivata na populacijo potočne postrvi v povezavi z MHE, saj ostali dejavniki absolutno dominirajo, obstaja pa povezanost med hitrostjo vodnega toka in substratom. V povprečju zasedajo potočne postrvi dele, kjer je hitrost vodnega toka med 20-50 cm/s (Greenberg, Svendsen, Harby, 1996; Heggenes, 1994). Manjše ribe imajo rajši počasnejši tok, večje ribe pa se izogibajo prepočasnemu toku (Heggenes, 1994). Potočne postrvi v normalnih pogojih raje izbirajo kamniti substrat z delci premera od 2-30 cm. Izogibajo se predelom s finejšim substratom. Večje ribe imajo rajši bolj grobi in večji oziroma skalni substrat, kar je verjetno povezano z zmanjšanjem hitrosti toka za večjo skalo. Skale jim nudijo tudi dobro kritje v primeru nevarnosti (Heggenes, 1994). Prav tako skale predstavljajo del prehranjevalnega teritorija, saj lahko ribe s samo občasnimi 'skoki' za hrano v glavni tok prihranijo veliko količino energije (Bachman, 1984).

\section{METODOLOGIJA}

Za oceno velikosti populacije potočne postrvi smo uporabili metodo elektroizlova. Poznamo štiri različne metode. Za potrebe naše raziskave smo uporabili kvantitativno metodo z brodenjem. Elektroizlov je potekal s pomočjo bencinskega elektroagregata ELT 60 GI z eno anodo in z možnostjo oddajanja napetosti v območju od 300-550 V. Višja je napetost, manj je možnosti pobega ribe in obratno. Elektroizlov smo opravili z brodenjem po toku navzgor $\mathrm{v}$ dveh ponovitvah.

Elektroizlove smo opravili pri treh MHE v zgornjem delu Mislinjske doline (Tomaška vas, Šentilj in Mislinja), na dveh 100-metrskih odsekih pod in nad MHE. Na ta način smo lahko primerjali odseke nad MHE, kjer vode ne odvzemajo in je zastopana čim bolj naravna populacija potočne postrvi, in odseke pod odvzemnimi mesti, kjer je zaradi odvzema v strugi veliko manj vode.

Vsak 100-metrski odsek smo spodaj in zgoraj omejili z mrežo, ki je preprečevala pobeg rib iz odseka. Med premikanjem (hojo) celotne ekipe po toku navzgor je en član odlovne ekipe upravljal z anodo, druga dva pa sta zajemala potočne postrvi s pomočjo dveh podmetalk. Dodatno sta dva člana ekipe odnašala ribe na mesto, kjer smo opravljali meritve ujetih osebkov. Za oceno naseljenosti in biomase potočne postrvi smo ribe na izbranih odsekih izlavljali dvakrat, obakrat z enako natančnostjo. Ujete potočne postrvi smo nato omamili z narkotikom (etilen glikol monofenil eter). Vsaki potočni postrvi smo nato ločeno po izlovih izmerili dolžino na mm natančno in maso (do $1 \mathrm{~g}$ natančno). Vse ujete potočne postrvi smo po analizi nepoškodovane vrnili v reko. 
Slika 3: Odseka vzorčenja pri MHE Tomaška vas

Figure 3: Sampling sections at small hydro power plant Tomaška vas

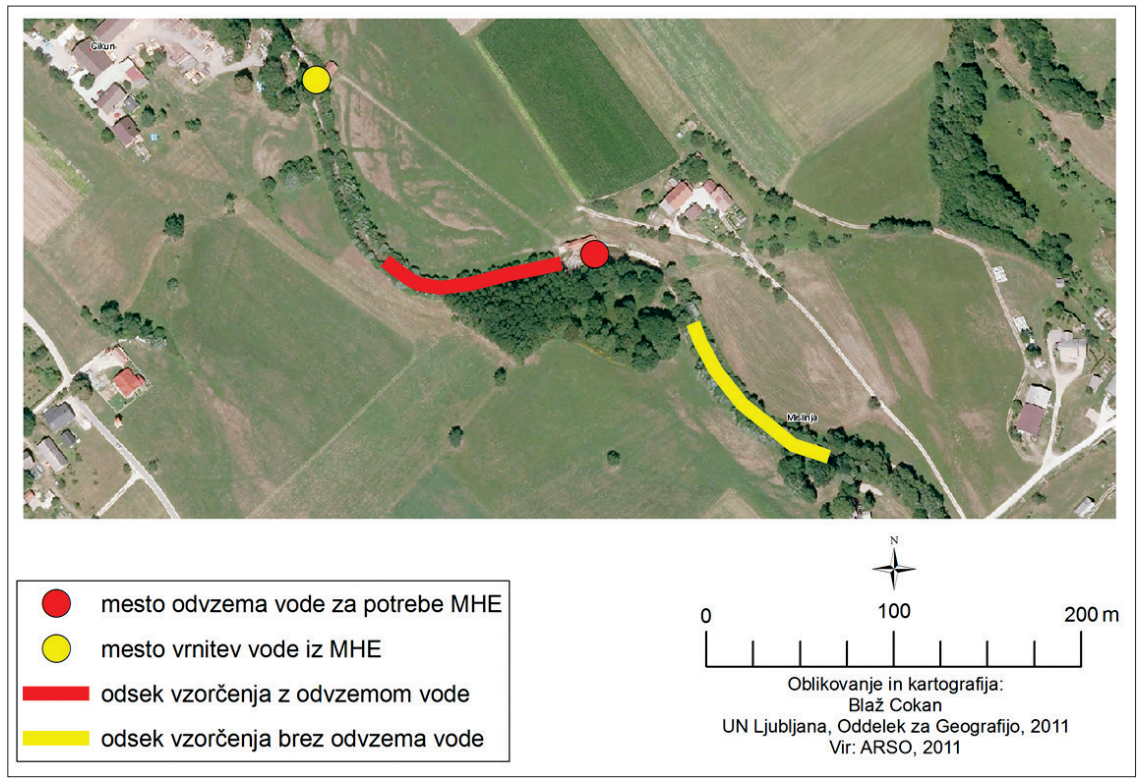

Slika 4: Odseka vzorčenja pri MHE Šentilj

Figure 4: Sampling sections at small hydro power plant Šentilj

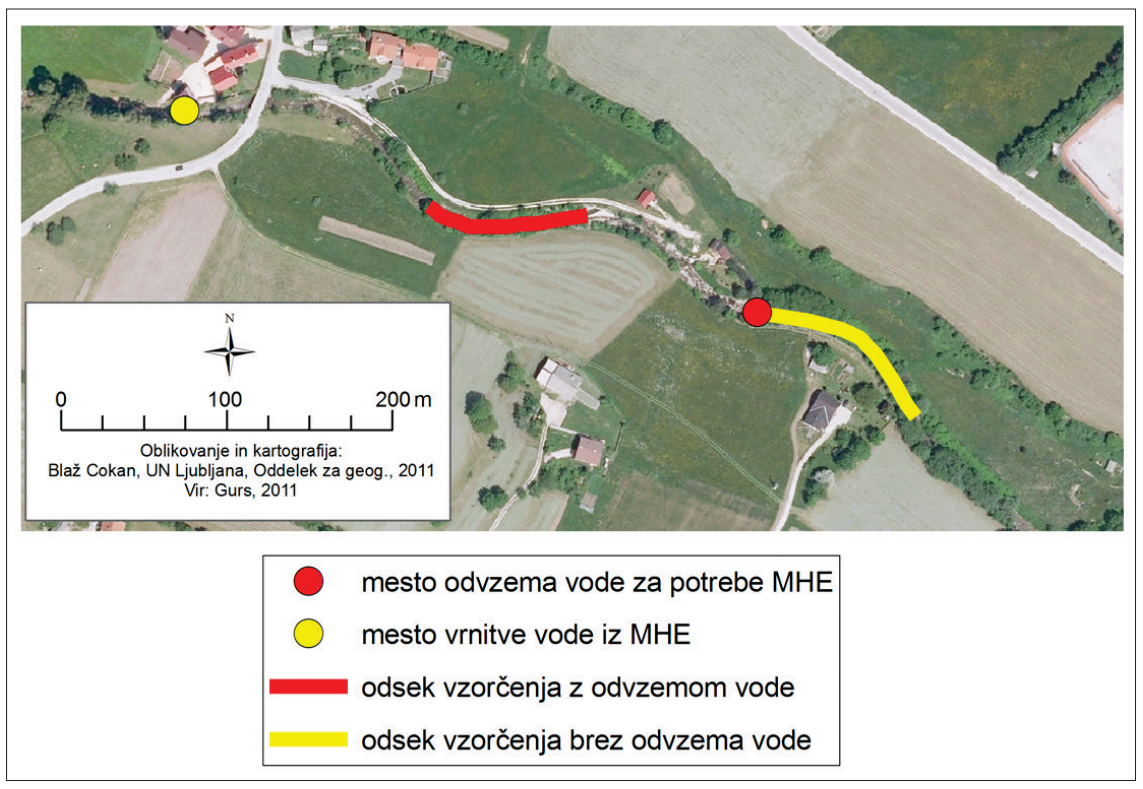


Slika 5: Odseka vzorčenja pri MHE Mislinja

Figure 5: Sampling sections at small hydro power plant Mislinja

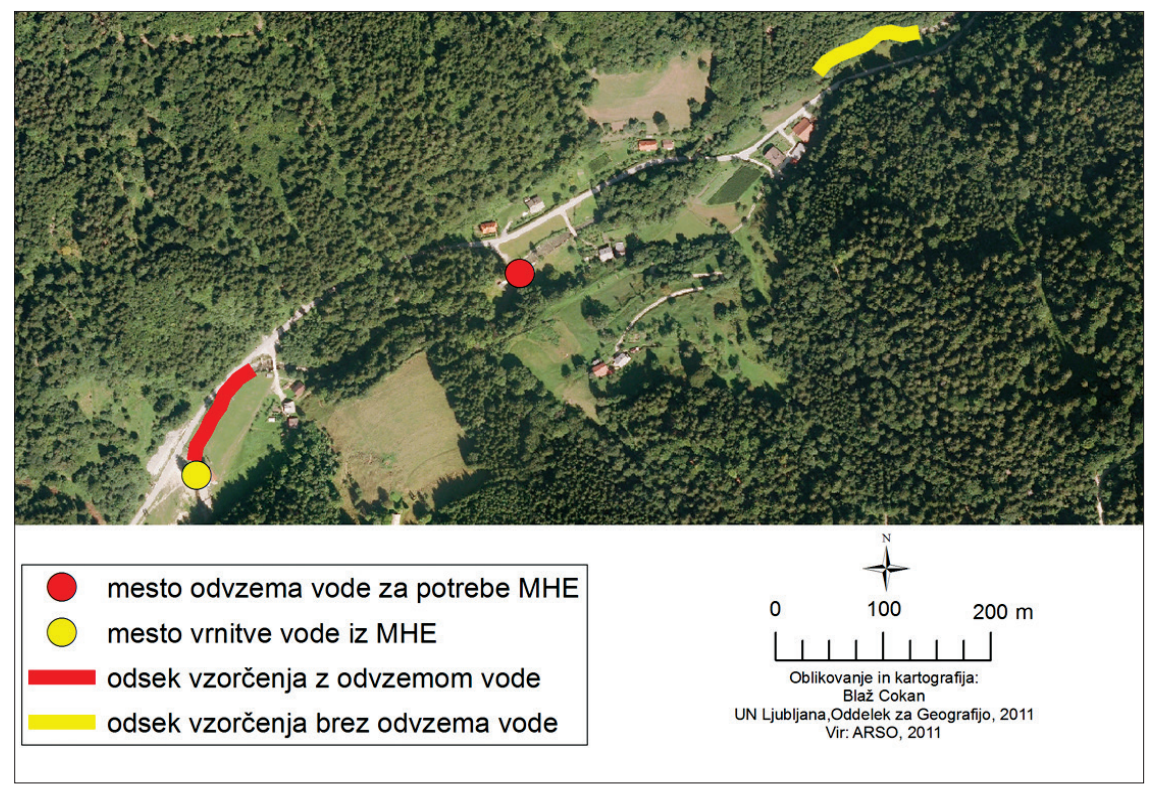

Na podlagi elektroizlova in opravljenih meritev smo izračunali število potočnih postrvi na $100 \mathrm{~m}^{2}$ vodotoka (ocena naseljenosti) ter biomaso potočne postrvi na $100 \mathrm{~m}^{2}$ $\left(\mathrm{kg} / 100 \mathrm{~m}^{2}\right)$ vodotoka.

Parametra smo izračunali po naslednji formuli (Seber, Le Cren, 1967):

$$
P[\mathrm{c} 1, \mathrm{c} 2]=\frac{\mathrm{n} !}{\mathrm{c} 1 !, \mathrm{c} 2 !(\mathrm{n}-\mathrm{c} 1-\mathrm{c} 2)} \mathrm{p}^{\mathrm{cl}}(\mathrm{qp})^{\mathrm{c} 2}\left(\mathrm{q}^{2}\right)^{\mathrm{n}-\mathrm{c} 1-\mathrm{c} 2}
$$

$\mathbf{n}=$ ocena velikosti populacije pred izlovom; $\mathbf{c 1}=$ stevilo ulovljenih rib v prvem izlovu; $\mathbf{c 2}=$ število ulovljenih rib v drugem izlovu; $\mathbf{p}=(1-q)=$ verjetnost, da je katerakoli riba ujeta; $\mathbf{q}=$ verjetnost, da riba ni ujeta; $\mathbf{P}=$ ocena velikosti populacije

$\mathrm{S}$ tem izračunom smo dobili vpogled $\mathrm{v}$ razlike $\mathrm{v}$ biomasi in naseljenosti potočnih postrvi med odseki nad MHE, kjer ni odvzema vode, in odseki pod MHE, kjer je zmanjšana količina vode zaradi odvzema za MHE. Prav tako smo izračunali povprečno dolžino in povprečno maso ujetih postrvi po posameznih odsekih. Za izračun biomase ter naseljenosti smo potrebovali tudi velikost vodne površine, ki smo jo izlovili na posameznem odseku. To smo dobili tako, da smo na terenu z metrom izmerili širino omočene struge in jo pomnožili z dolžino odseka.

Poleg elektroizlova smo izmerili tudi pretok reke Mislinje na vseh šestih vzorčnih odsekih. Pretok smo izmerili s posebno napravo za merjenje pretokov, ki se imenuje Flo Tracer. 


\section{VPLIV MHE NA POPULACIJO POTOČNE POSTRVI}

Pred elektroizlovom smo izmerili pretoke na preučevanih odsekih ter s tem potrdili, da so pretoki na odsekih pod MHE bistveno manjši kot na odsekih nad MHE. Ugotovili smo, da je bil pretok pod MHE Tomaška vas manjši za 97 \%, pod MHE. Šentilj za 98 \% in pod MHE Mislinja za $91 \%$ (slika 8).

Slika 6: MHE Tomaška vas (foto: B. Cokan)

Figure 6: Small hydro power plant Tomaška vas (photo: B. Cokan)

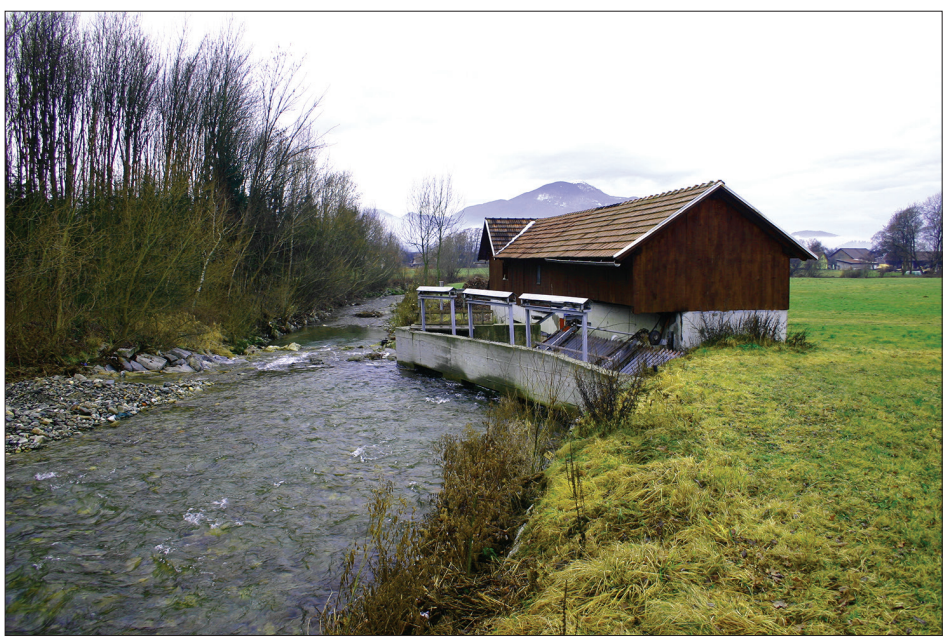

Slika 7: Odsek reke Mislinje nad MHE Mislinja (foto: B. Cokan)

Figure 7: Sampling section on Mislinja River above the small hydro power plant Mislinja (photo: B. Cokan)

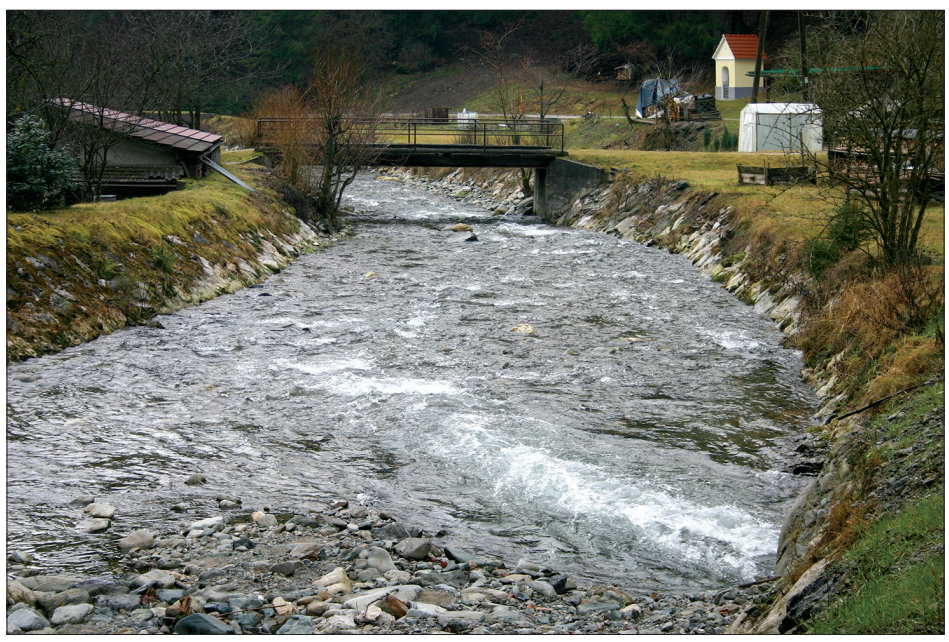


Slika 8: Odsek reke Mislinje pod MHE Mislinja (foto: B. Cokan)

Figure 8: Sampling section on Mislinja River below the small hydro power plant Mislinja (photo: B. Cokan)

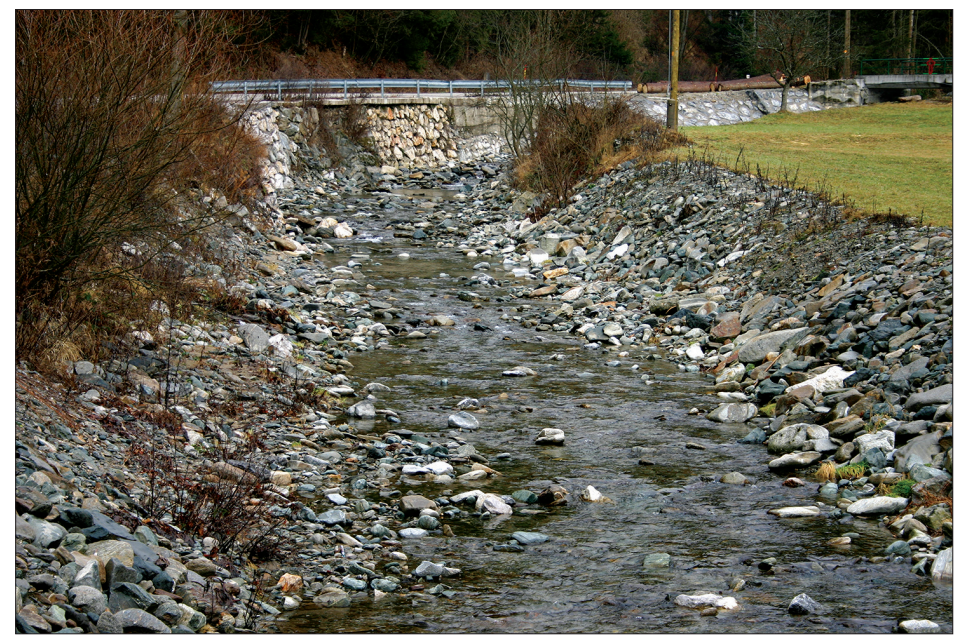

Z analizo dobljenih podatkov smo ugotovili, da so se biomasa, povprečna dolžina in povprečna masa potočnih postrvi na odsekih pod MHE, kjer je zmanjšana količina vode zaradi odvzema, zmanjšale v primerjavi z odseki nad MHE, kjer odvzema ni (preglednica 1; slike 9-12). Prav tako je upadlo število ujetih postrvi.

Najpomembnejši pokazatelj zmanjšanja populacije je biomasa. Pri MHE Tomaška vas se je na odseku pod odvzemnim mestom biomasa zmanjšala za $0,32 \mathrm{~kg} / 100 \mathrm{~m}^{2}$, pri MHE Šentilj za 0,30 kg/100 $\mathrm{m}^{2}$ in pri MHE Mislinja za 0,20 kg/100 m² (slika 9).

Preglednica 1: Značilnosti populacije potočne postrvi po odsekih Table 1: Characteristics of brown trout population by sections

\begin{tabular}{|l|c|c|c|c|c|c|}
\hline \multirow{2}{*}{ PARAMETRI } & \multicolumn{2}{|c|}{ MHE Tomaška vas } & \multicolumn{2}{c|}{ MHE Šentilj } & \multicolumn{2}{c|}{ MHE Mislinja } \\
\cline { 2 - 7 } & $\begin{array}{c}\text { Odsek } \\
\text { nad } \\
\text { MHE } \\
\text { (brez } \\
\text { odvzema } \\
\text { vode) }\end{array}$ & $\begin{array}{c}\text { Odsek } \\
\text { pod } \\
\text { MHE } \\
\text { (odvzem } \\
\text { vode) }\end{array}$ & $\begin{array}{c}\text { Odsek } \\
\text { nad } \\
\text { MHE } \\
\text { (brez } \\
\text { odvzema } \\
\text { vode) }\end{array}$ & $\begin{array}{c}\text { Odsek } \\
\text { pod } \\
\text { MHE } \\
\text { (odvzem } \\
\text { vode) }\end{array}$ & $\begin{array}{c}\text { Odsek } \\
\text { nad } \\
\text { MHE } \\
\text { (brez } \\
\text { odvzema } \\
\text { vode) }\end{array}$ & $\begin{array}{c}\text { Odsek } \\
\text { pod } \\
\text { MHE } \\
\text { (odvzem } \\
\text { vode) }\end{array}$ \\
\hline $\begin{array}{l}\text { Število ujetih potočnih } \\
\text { postrvi }\end{array}$ & 135 & 67 & 118 & 82 & 101 & 74 \\
\hline Naseljenost (število/100 $\left.\mathrm{m}^{2}\right)$ & 23 & 22 & 24 & 27 & 17 & 24 \\
\hline Biomasa $\left(\mathrm{kg} / 100 \mathrm{~m}^{2}\right)$ & 1,14 & 0,82 & 0,75 & 0,45 & 0,77 & 0,57 \\
\hline Povprečna dolžina $(\mathrm{cm})$ & 13,3 & 11,7 & 11,7 & 8,6 & 15,6 & 12,1 \\
\hline Povprečna masa $(\mathrm{g})$ & 49,6 & 36,7 & 31,7 & 16,5 & 45,6 & 23,2 \\
\hline
\end{tabular}


Slika 9: Biomasa potočnih postrvi na odsekih nad in pod MHE

Figure 9: Brown trout biomass above (blue) and below (red) small hydro power plants

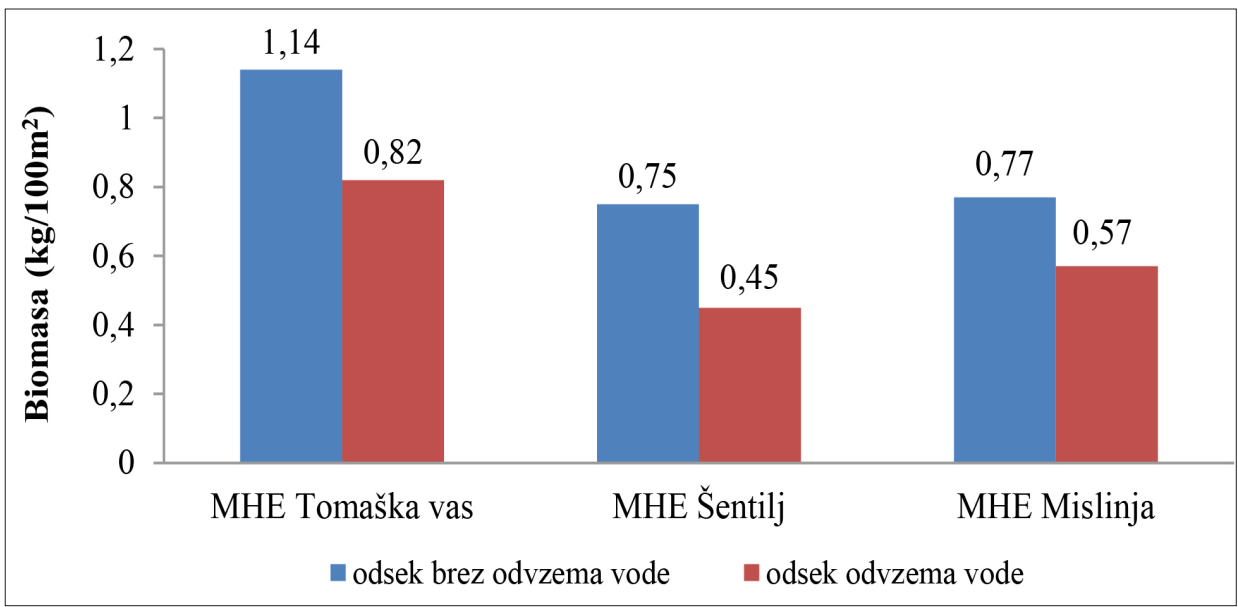

Drugi pomemben pokazatelj zmanjšanja populacije potočne postrvi je povprečna masa potočnih postrvi. Pri MHE Tomaška vas se je povprečna masa pod odvzemnim mestom zmanjšala za 26 \%, pri MHE Šentilj za 48 \% in pri MHE Mislinja za $49 \%$.

Slika 10: Povprečna masa potočnih postrvi na odsekih nad in pod MHE

Figure 10: Brown trout average mass above (blue) and below (red) small hydro power plants

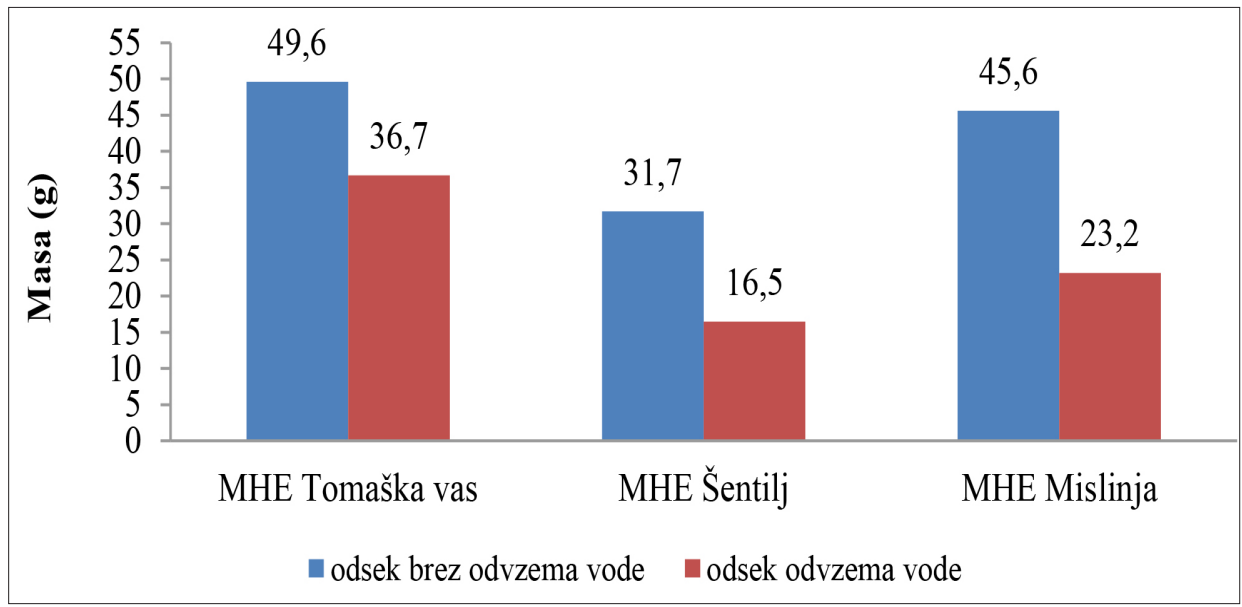

Tretji pomemben pokazatelj zmanjšanja populacije potočne postrvi je povprečna dolžina potočnih postrvi. Pri MHE Tomaška vas se je povprečna dolžina pod odvzemnim mestom zmanjšala za $12 \%$, pri MHE Šentilj za $27 \%$ in pri MHE Mislinja za $23 \%$ (slika 11). 
Slika 11: Povprečna dolžina potočnih postrvi na odsekih nad in pod MHE

Figure 11: Brown trout average lenght above (blue) and below (red) small hydro power plants

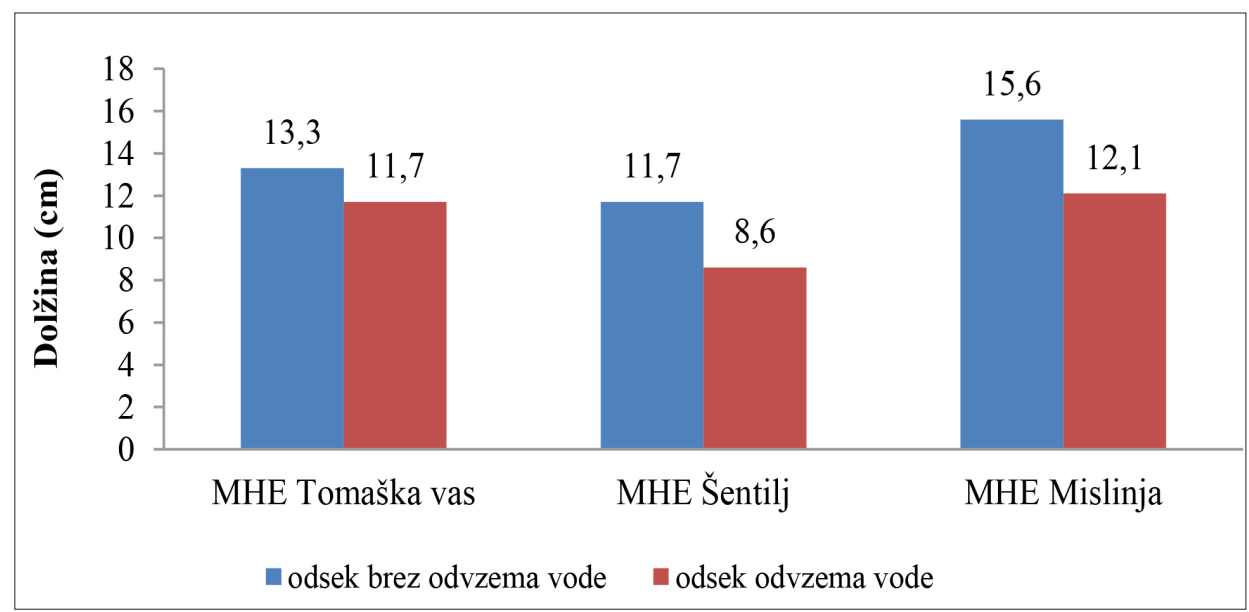

Četrti pokazatelj zmanjšanja populacije potočne postrvi je število osebkov v populaciji. Pri MHE Tomaška vas se je število ujetih potočnih postrvi pod odvzemnim mestom zmanjšalo za 50 \%, pri MHE Šentilj za $31 \%$ in pri MHE Mislinja za 27 \%.

Razlog za upad biomase, povprečne dolžine in povprečne mase ter števila potočnih postrvi na odsekih, kjer odvzemajo vodo za MHE, so zmanjšani pretoki. Ti negativno vplivajo na globino, kritje, konkurenco in plenilstvo ter količino drifta.

Slika 12: Število ujetih potočnih postrvi na odsekih nad in pod MHE

Figure 12: Number of captured fish above (blue) and below (red) small hydro power plants

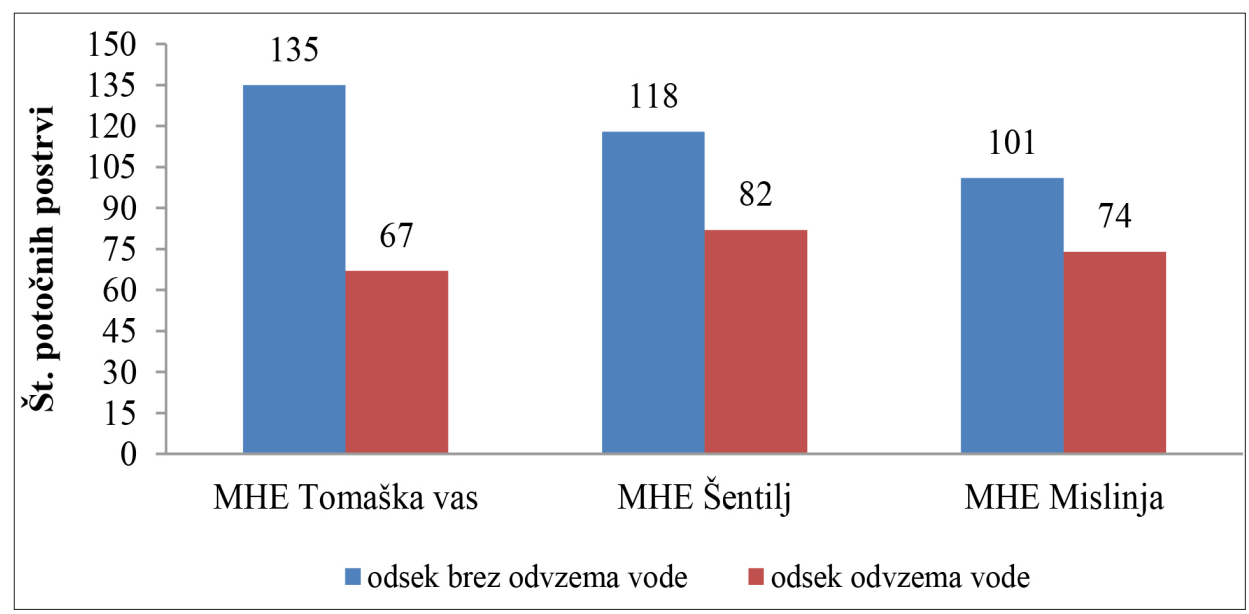


Ob upadu pretoka postane voda v strugi plitvejša. To povzroči zmanjšanje življenjskega prostora oziroma vodne površine, ki jo naseljujejo potočne postrvi. Posledično izginejo številni mikrohabitati za kritje, ki so bistveni dejavnik za preživetje potočne postrvi. $\mathrm{Z}$ zmanjšanjem vodne površine in upadom primernih prostorov za kritje se povečata tudi konkurenca in plenilstvo med osebki. Z zmanjšanjem življenjskega prostora upade tudi količina drifta oziroma količina potencialne hrane za potočno postrv, ki jo prinaša vodni tok. Potočna postrv potrebuje za svoj obstoj določeno površino, kjer se hrani, kjer ima prostor za počitek in ki ji nudi dovolj kritja pred plenilci (ptice, večji osebki potočne postrvi in človek).

Globina je eden od glavnih dejavnikov, ki vplivajo na velikost populacije potočne postrvi v vodotokih, še posebej v manjših potokih. Zaradi manjšega pretoka je ravno zmanjšana globina tista, ki vpliva na velikost populacije. Z odvzemom vode se zmanjša število tolmunov, mest s kritjem in življenjski prostor. Zato se vse potočne postrvi skoncentrirajo v preostalih globljih predelih, kar poveča konkurenco in izpostavljenost teh rib plenilcem.

Kritje je skupaj z globino vode najpomembnejši dejavnik, ki omejuje gostoto populacije potočne postrvi. Z izginjanjem primernih mest za kritje se poveča izpostavljenost pred plenilci, kar privede do upada populacije. Regulacije in drugi antropogeni posegi še dodatno zmanjšajo število primernih mest za kritje.

Slika 13: Posledice zmanjšanega pretoka na populacijo potočne postrvi

Figure 13: Consequences of water abstraction on the population of brown trout

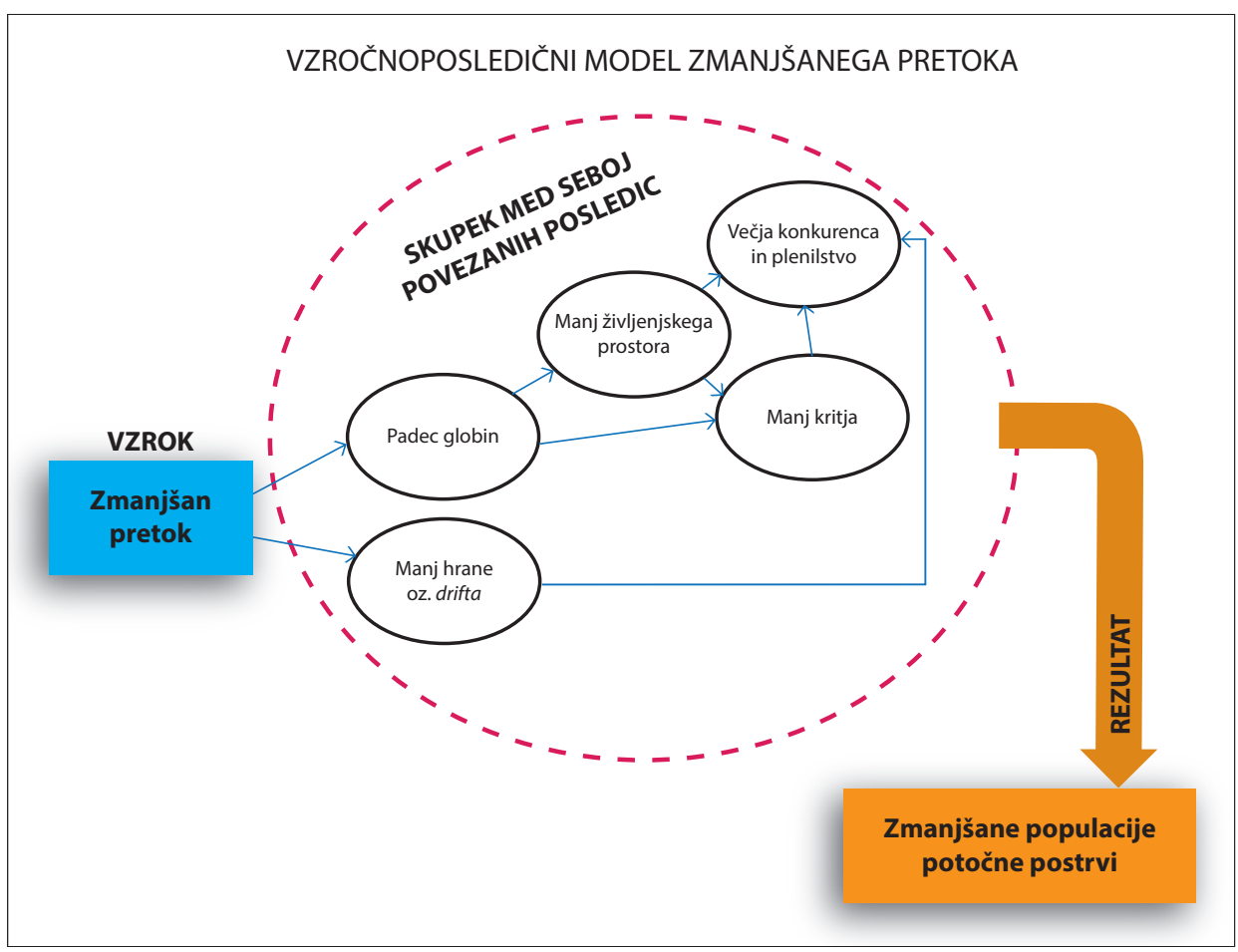


$\mathrm{Z}$ zmanjšanjem pretoka se konkurenca in plenilstvo $\mathrm{v}$ začetni fazi močno povečata, saj upadejo globina vode, število primernih mest za kritje, število najprimernejših mikrohabitatov ter količina hrane, naseljenost pa ostane na ravni, kot je bila pred odvzemom vode. Ko se populacija potočne postrvi zmanjša, se zmanjšata tudi plenilstvo in konkurenca. Populacija se nato ne more več povečati, saj lahko na določeni površini vodotoka sobiva le določeno število osebkov.

Zmanjšan pretok negativno vpliva tudi na število vodnih organizmov, ki so potencialna hrana za potočne postrvi, saj se z zmanjševanjem življenjskega prostora ta zmanjša tudi za vodne organizme, ki so hrana potočne postrvi. Prav tako odnese voda večino vodnih organizmov v driftu skozi kanal v MHE, saj tja odteka večina vode, in le majhen del po matični strugi. Manj hrane pomeni večjo konkurenco pri hranjenju ter posledično manjšo populacijo potočne postrvi.

Če z izgradnjo MHE odvzamemo del življenjskega prostora, kritja in hrane, hkrati pa se kot posledica tega povečata konkurenca in plenilstvo, to privede do upada populacije potočne postrvi. Na določeni vodni površini pač lahko preživi le določeno število osebkov z maso in dolžino, ki ustreza velikosti njihovega življenjskega prostora.

Poleg že predstavljenih parametrov velikosti populacije potočne postrvi in razlogov za upad smo na podlagi podatkov, pridobljenih z vzorčenjem, izračunali tudi naseljenost populacije potočne postrvi. Ugotovili smo, da se naseljenost potočnih postrvi na odsekih, kjer odvzemajo vodo za MHE v primerjavi z odseki nad MHE, kjer odvzema ni, ni pomembno spremenila, le minimalno se je zmanjšala ali celo rahlo povečala.

Določena vodna površina lahko sprejme le omejeno število osebkov. Če se pretok in s tem vodna površina zmanjšata, upade tudi število osebkov, sorazmerno z zmanjšanjem površine. Le kadar se z zmanjšanjem pretoka bistveno spremeni življenjski prostor (kritje, globina, hitrost vodnega toka, hrana itd.), se lahko število osebkov spremeni tudi nesorazmerno

\section{Slika 14: Naseljenost potočnih postrvi na odsekih nad in pod MHE}

Figure 14: Brown trout abundance above (blue) and below (red) small hydro power plant

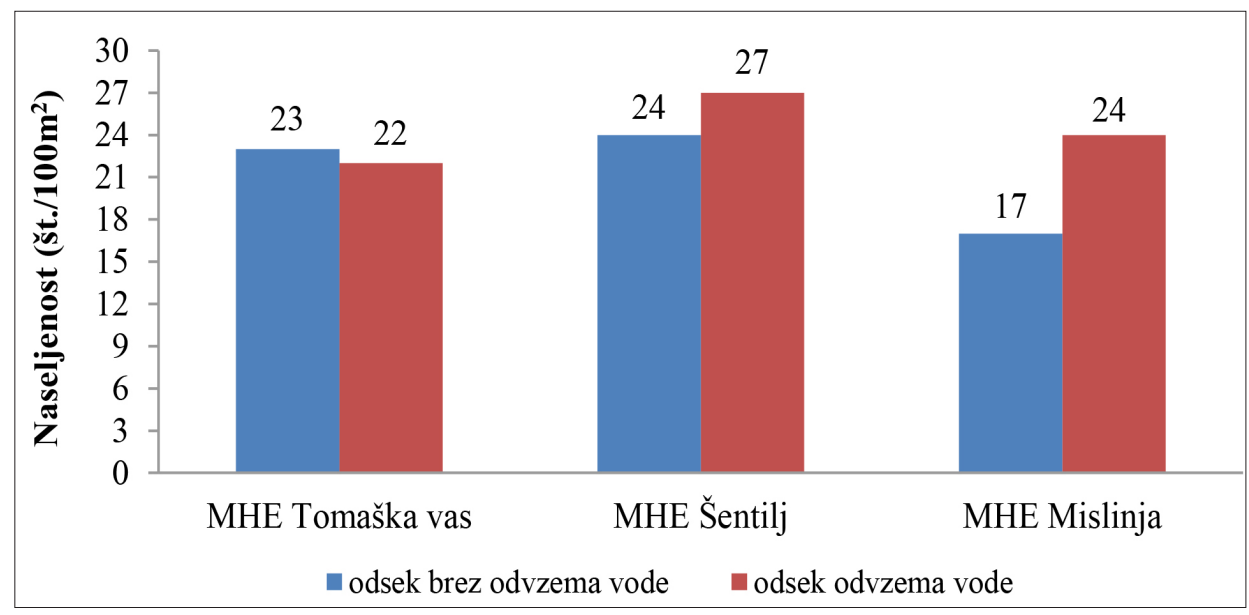


z zmanjševanje vodne površine, kar pa se v našem primeru ni zgodilo, saj je naseljenost v prvih dveh primerih ostala na približno enaki ravni. Le pri MHE Mislinja se je naseljenost povečala na odseku pod mestom odvzema vode (slika 8). Razlog pripisujemo mladicam potočnih postrvi. Obstaja velika verjetnost, da je te osebke na odseke, kjer odvzemajo vodo za MHE, naknadno prinesla visoka voda in so tukaj našle primeren habitat, ki jim nudi zaščito pred večjimi osebki potočne postrvi ter počasnejši vodni tok. Višjo naseljenost je možno razložiti tudi s povezavo med povprečno velikostjo potočnih postrvi in drstjo. Ker je povprečna dolžina potočnih postrvi na odsekih, kjer odvzemajo vodo za MHE, manjša kot na odsekih, kjer odvzema ni, lahko sklepamo, da je na teh odsekih manj kanibalizma s strani večjih osebkov. Zaradi tega $\mathrm{v}$ povezavi z dobro drstjo preživi več mladic.

\section{SKLEP}

Elektroizlove smo izvedli pri treh MHE (Tomaška vas, Šentilj in Mislinja), ki obratujejo na reki Mislinji. Pri vsaki smo izbrali po dva 100-metrska odseka, enega nad MHE, kjer ni odvzema vode in je zastopana čim bolj naravna populacija potočne postrvi, ter enega pod MHE, kjer odvzemajo vodo za MHE. Na vsakem od teh odsekov smo ujetim osebkom izmerili dolžino in maso in te podatke uporabili za izračun biomase, naseljenosti, povprečne dolžine in povprečne mase. S temi parametri smo nato poskušali dokazati, da je populacija potočne postrvi upadla na odsekih, kjer odvzemajo vodo za MHE. Hkrati smo tudi z merjenjem potrdili, da so pretoki na odsekih, kjer je voda odvzeta za potrebe MHE, dejansko nižji kot na odsekih, kjer odvzema vode ni.

$Z$ raziskavo smo ugotovili, da so na vseh treh odsekih, kjer odvzemajo vodo za MHE, biomasa, povprečna dolžina in povprečna masa populacije potočnih postrvi upadle. Upadlo je tudi absolutno število ujetih postrvi. S tem smo potrdili, da se je populacija potočne postrvi na teh odsekih zmanjšala. Razlog smo pripisali zmanjšanju pretoka, s katerim so se zmanjšali globina vode, število tolmunov, število primernih mest za kritje in količina hrane oziroma drifta. Hkrati sta se na teh odsekih povečala konkurenca in plenilstvo.

Prav tako smo ugotovili, da naseljenost na odsekih pod MHE, kjer odvzemajo vodo za MHE, ni upadla. Pri MHE Tomaška vas in Šentilj je ostala na približno enaki ravni, kar je razumljivo, saj z zmanjšanjem življenjskega prostora sorazmerno upade tudi število potočnih postrvi in obratno. Pri MHE Mislinja se je naseljenost na odseku pod MHE, kjer odvzemajo vodo za MHE, celo povečala. Razlog za to je lahko visoka voda, ki je na ta odsek prinesla mladice potočne postrvi. Te so tukaj našle primeren habitat s počasnejšim vodnim tokom. Drugi razlog lahko pripišemo upadu povprečne dolžine potočnih postrvi na teh odsekih, saj se manjše potočne postrvi v manjši meri prehranjujejo z mladicami iste vrste.

\section{SLOVARČEK MANJ ZNANIH IZRAZOV}

Anoda:

Pozitivna elektroda v obliki podmetalke, ki je neposredno povezana z električnim agregatom in služi za oddajanje električnega toka. Vplivno območje električnega toka, ki ga oddaja anoda, je približno do 2 m okoli anode. 
Brodenje: Hoja odlovne ekipe po toku navzgor.

Drift: Odnašanje bentosa po toku navzdol s hitrostjo toka. Možno je odnašanje bentosa zaradi premočnega toka, ki se mu bentos ne more zoperstaviti, ali zaradi rojenja ličink, ki se prosto spuščajo s tokom.

Električni agregat: Elektronsko-mehanska naprava v obliki nahrbtnika, ki oddaja električni tok različnih napetosti. Sestavljen je iz bencinskega motorja, elektronskega vezja, anode, katode in ogrodja.

Elektroizlov: Postopek, s katerim se s pomočjo električnega agregata odlavlja ribe v izbranem odseku vodotoka. Anoda oddaja električni tok, ki za kratek čas povzroči mišične krče pri ribah in posledično delno nezmožnost gibanja. Električni tok povzroči, da se ribe počasi in omejeno gibljejo proti anodi. Te ribe nato člani odlovne ekipe sproti zajemajo s podmetalko.

Katoda: Negativna elektroda, sestavljena iz številnih med seboj prepletenih bakrenih žic $\mathrm{v}$ dolžini dveh metrov, ki je neposredno povezana $\mathrm{z}$ električnim agregatom. Skupaj z anodo omogoča kroženje električnega toka.

Kritje: $\quad$ Prostor v vodotoku, kjer se lahko riba skrije pred nevarnostjo oziroma pred različnimi vodnimi in kopenskimi plenilci.

Naseljenost: $\quad$ Stevilo osebkov, ki živijo na določeni površini vodotoka (npr. na $100 \mathrm{~m}^{2}$ ).

Podmetalka: $\quad$ Pripomoček za zajemanje rib, ki jih električni tok delno paralizira. Sestavljena je iz dolgega ročaja in globoke mreže, s katero se zajema ribe.

\section{Viri in literatura}

Bachman, R. A., 1984. Foraging behavior of free-ranging wild and hatchery brown trout in a stream. Transactions of the American Fisheries Society, 113, str. 1-32.

Bernatchez, L., 2001. The evolutionary history of brown trout (Salmo trutta L.) inferred from phylogeographic, nested clade, and mismatch analyses of mitochondrial DNA variation. Evolution, 55, 2, str. 351-379.

Cokan, B., 2012. Vpliv malih hidroelektrarn na populacijo potočne postrvi na primeru reke Mislinje. Diplomsko delo. Ljubljana, Filozofska fakulteta, Oddelek za geografijo, 92 str. URL: http://geo2.ff.uni-lj.si/pisnadela/pdfs/dipl_201210_blaz_cokan.pdf (Citirano 12. 9. 2013).

Degerman, E., Sers, B., 1993. A study of interactions between fish species in streams using survey data on the PCA-hyperspace technique. Nordic journal of freshwater research, 68, str. 5-13.

Elliott, J. M., 1981. Some aspects of thermal stress on freshwater teleosts. V: Pickering, A. D. (ur.). Stress and fish. London, Academic Press, str. 209-245.

Gams, I., 1998. Geografske značilnosti Slovenije. 2. natis. Ljubljana, Mladinska knjiga, 183 str. 
Greenberg, L., Svendsen, P., Harby, A., 1996. Availability of microhabitats and their use by brown trout (Salmo trutta) and grayling (Thymallus thymallus) in the river Vojman, Sweden. Regulated rivers: research \& management, 12, 2-3, str. 287-303.

Hansen, M. M., Loeschcke, V., 1994. Effects of releasing hatchery-reared brown trout to wild trout populations. Conservations genetics, 68, str. 273-290.

Hart, P. J. B., 1986. Foraging in teleost fishes. V: Pitcher, T. J. (ur.). The behaviour of teleost fishes. London, Chapman \& Hall, str. 211-235.

Heggenes, J., 1994. Physical habitat selection by brown trout (Salmo trutta) and young Atlantic salmon $(S$. salar) in spatially and temporally heterogeneus streams. Implications for hydraulic modelling. V: Proceedings of the 1 st international symposium of habitat hydraulic. River research and aplications. Trondheim, Norwegian Institute of Technology, str. 12-30.

Hidrološki letopis Slovenije 2008. Ljubljana, Agencija Republike Slovenije za okolje in prostor. URL: http://www.arso.gov.si/vode/poro\%C4\%8Dila $\% 20$ in $\% 20$ publikacije/III.A.\%20Povr\%C5\%A1inske\%20vode_Surface\%20Waters.pdf (Citirano 13. 10. 2013).

Kalleberg, H., 1958. Observations in a stream tank of territoriality and competition in juvenile salmon and trout (Salmo salar L. and Salmo trutta L.). Report of the Institute of Freshwater Research, 39, str. 55-98.

Laikre, L., 1999. Hereditary defects and conservation genetic management of captive populations. Zoo biology, 18, 2, str. 81-99.

Mortensen, E., 1977. Density-dependent mortality of brown trout fry (Salmo trutta L.) and its relationship to the management of small streams. Journal of fish biology, 11, str. 613-617.

Nielsen, G., 1986. Dispersion of brown trout Salmo trutta L. in relation to stream cover and water depth. Polskie archiwum hydrobiologii, 33, 3-4, str. 475-488.

Povž, M., Sket, B., 1990. Naše sladkovodne ribe. Ljubljana, Mladinska knjiga, 369 str.

Rasmussen, G., 1986. The population dynamics of brown trout (Salmo trutta L.) in relation to year-class size. Polskie archiwum hydrobiologii, 33, str. 489-508.

Seber, G. A. F., Le Cren, E. D., 1967. Estimating population parameters from catches large relative to the population. Journal of animal ecology, 36, str. 631-643.

Slaney, P. A., Northcote, T. G., 1974. Effects of prey abundance on density and territorial behaviour of young rainbow trout (Salmo gairdneri) in laboratory stream channels. Journal of the Fisheries Research Board of Canada, 31, str. 1201-1209.

Svetina, M., 1987. Sladkovodno ribištvo na Slovenskem: ribiški zbornik. 2. dopolnjena izdaja. Ljubljana, Ribiška zveza Slovenije, 343 str. 


\section{INFLUENCE OF SMALL HYDRO POWER PLANTS ON BROWN TROUT POPULATION IN MISLINJA RIVER}

\section{Summary}

Electrofishing was performed at three small hydro power plants (Tomaška vas, Šentilj and Mislinja) operating on the Mislinja River. We selected two water sections in the length of one hundred meters at each power plant. One of the sections was upstream of the power plant, where there is no drainage and the brown trout population is mostly naturally represented. The other section was chosen downstream of the power plant, where the water is being drained for the power plant. In each section, the length and mass of the fish were measured to calculate their biomass, abundance, average length and average mass. These indicators were used to prove that the population of brown trout subsides on the sections where the water is abstracted for the power plant. At the same time as electrofishing, we measured the water discharge on the sampling sections and thus confirmed the hypothesis that the water discharge is really lower below the power plant than in the upstream sections where the water is not taken away.

The investigation showed a decline in the biomass, average length and average mass on all three sections where the water is drained for the hydroelectric power plants. The absolute number of caught trout has also declined. We have thus confirmed a reduction of the brown trout population in these sections. We attributed the reason for this to the diminished water discharge and the subsequently shallower waters, lower number of pools, fewer places for cover and a diminished quantity of food or drift. At the same time, the levels of competition and plundering increased.

We also determined that the abundance of brown trout on sections where water is drained for the hydro power plants has not diminished. In the cases of the Tomaška vas and Šentilj power plants it has remained at about the same level. This is logical since the number of brown trout reduces in proportion to the shortening of life space and vice versa. For the Mislinja power plant, the density has even increased in the section where the water is drained. The reason for this might be in the higher water levels which brought the brown trout's juveniles to these sections where they found a suitable habitat with a slower water flow. Another reason could be attributed to the reduced average length of brown trout in these sections since the smaller brown trouts are less likely to feed on the juveniles of the same species.

(Translated by the authors) 